\title{
VÍSCERAS, SANGUE E METAFÍSICA PSICOSSOMÁTICA
}

\author{
VISCERA, BLOOD AND PSYCHOSOMATIC METAPHYSICS
}

\author{
Luciano Coutinho
}

\begin{abstract}
É Doutor em Estudos Clássicos / Filosofia Antiga pela Universidade de Coimbra - UC (recebeu bolsa CAPES para Doutorado Pleno no Exterior). É Pós-Doutor em Filosofia pela Universidade Federal de Uberlândia - UFU (recebeu bolsa CAPES). É atualmente Pós-Doutorando em Filosofia pela Universidade do Minho - UM; e Pós-Doutorando em Filosofia pela Universidade Federal de Uberlândia - UFU. É Mestre em filosofia pela Universidade de Brasília - UnB, e Mestre em Arquitetura e Urbanismo (com ênfase em Estética e Semiótica) pela Universidade de Brasília - UnB.
\end{abstract}

\begin{abstract}
RESUMO
As vísceras e o sangue humanos têm sido temáticas bastante recorrentes em nossos registros rituais e míticos ao longo de nossa história. Embora pareçam ser elementos meramente físicos, eles assumem simbologia estreitamente ligada a princípios metafísicos. Nesse sentido, aquilo que se apresenta como grotesco torna-se caminho necessário para o melhoramento do humano. Nesse sentido, buscaremos analisar alguns ritos e mitos ligados à cultura indígena, egípcia e cristã, que recorrem a essa temática, a fim de demonstrar como a imagem grotesca das vísceras e do sangue humanos busca fundamentar caminhos para a ideia de uma existência metafísica. Tentaremos, nesse sentido, demonstrar em que medida tal associação poderia ser fruto de um conhecimento psicossomático intuitivo da própria mente humana.

Palavras-chave: Vísceras; Sangue; Metafísica; Psicossomática.
\end{abstract}

\begin{abstract}
Human viscera and blood have been recurring themes in our ritual and mythical records throughout our history. Although they appear to be merely physical elements, they assume symbolism closely linked to metaphysical principles. In this sense, what appears as grotesque becomes a necessary modality for the improvement of the human. In this sense, we will try to analyse some rites and myths related to the indigenous, Egyptian and Christian culture, connected with this theme, in order to demonstrate how the grotesque image of human viscera and human blood seeks to ground ways for the idea of a metaphysical existence. In this sense, we will try to show how this association could be the result of an intuitive psychosomatic knowledge of the human mind itself.
\end{abstract}

Keywords: Viscera; Blood; Metaphysics; Psychosomatic.

\section{Rito de comunhão}

Antes da vinda dos europeus para a América do Sul, muitos nativos ritualizavam a antropofagia. Alguns cronistas portugueses relataram com certo horror e repugnância algumas dessas práticas, confundindoas com canibalismo. Um dos maiores exemplos disso é Gândavo em 1576:

${ }^{1}$ Temos, com o protestante alemão Hans Staden, uma interessante associação da alimentação pela bebida feita com abbatis (milho) e raiz de mandioca com o canibalismo: "Quando voltam de uma guerra, querem ter os abbatis (milho) para fabricarem essa bebida, que é para quando comem os inimigos, si tiverem capturado algum, e durante o anno inteiro esperam com impaciencia o tempo dos abbatis" (STADEN, 1930, p.58 [texto original de 1557]).
Não dão vida a nenhum cativo, todos matão e comem, enfim que suas guerras são mui perigosas (...) Depois que comem a carne destes contrarios ficão nos odios confirmados e sentem muito esta injuria, e por isso andão sempre a vingar-se huns contra os outros (...) Tambem pela terra (a) dentro matão e comem alguns indios quando se achão famintos (GÂNDAVO, 1980, p. 15; p. 16; p. 19 [texto original de 1576]).

Além de Gândavo, uma longa lista de autores leigos e confessionais, portugueses e não portugueses, legou um caráter canibalista às práticas antropofágicas dos índios que aqui habitavam antes da colonização: Hans Staden $^{1}$ (1557), Jean de Péry (1578), Gabriel Soares de 
Sousa (1587), Fernão Cardim (1625), Frei Vicente do Salvador (1627), dentre muitos outros.

O ritual indígena consiste em comer das vísceras e/ou beber do sangue de um inimigo capturado ${ }^{2}$, nas pode também ser associada ao contato tátil: "incrível crueldade, assim como os nossos caçadores jogam a carniça aos cães para torná-los mais ferozes, esses selvagens pegam os filhos uns após outros e lhes esfregam o corpo, os braços, e as pernas com o sangue inimigo a fim de torná-los mais valentes" (JEAN DE PÉRY, 1961, p. 157; trad. Milliet do original de 1578). Jean de Péry entende esta prática como cruel e física, pois, para ele, não se trata de uma questão de transmissão de qualidades, mas antes de um estágio de animalização do homem, recorrendo aos instintos mais primitivos.

Neste trabalho, no entanto, entendemos a antropofagia ${ }^{3}$ como uma prática ritual, em que a crença gira em torno da ideia de que, ao alimentar-se da carne e/ou do sangue de um grande guerreiro inimigo, algumas de suas determinadas qualidades seriam transmitidas para o antropófago. Um inimigo pode representar fonte de qualidades desejadas por um guerreiro para as próximas batalhas. Comer de suas vísceras e/ou beber de seu sangue, portanto, significa antes a transmissão de suas qualidades para quem ritualizar com ele. Isto poderia, segundo a crença em torno dessa prática, determinar a vitória ou a derrota de um guerreiro.

Um dos rituais mais conhecidos dos nossos dias é a Comunhão da Igreja Católica. A ideia da transubstanciação do pão, em corpo, e do vinho, em sangue, está ligada ao princípio de melhoramento daquele que ritualiza com Cristo. Comer do corpo e beber do sangue da divindade nos revela, em primeiro lugar, o deseja de se adquirir suas qualidades, e, em segundo lugar, a possibilidade de buscar melhorar-se a partir do ritual de Comunhão. O cronista e pastor protestante francês, Jean de Péry ${ }^{4}$, havia, em 1578, feito análises comparativas entre a antropofagia indígena e a Comunhão católica, mas suas intenções eram duas: à familiarização de seu leitor europeu com as práticas indígenas, em primeiro lugar; à desvalorização da prática católica da Comunhão, em segundo lugar.

Não estamos interessados nesse tipo de contenda entre protestantes e católicos, muito comuns entre os séculos XVI e XVIII, mas antes na simbologia metafísica de tais imagens rituais.

Se Cristo é uma divindade que veio ao mundo em forma humana, sofreu, foi humilhado, morto, ressuscitado e depois sentou-se à direita de $\mathrm{YHWH}$, comer de seu corpo e beber de seu sangue significa que a miséria da vida humana se torna um tipo de etapa para a ascensão divinal, daqueles que se assemelharem a Cristo. Nesse sentido, buscar assemelhar-se a Cristo significa assumir o desejo de tornar-se capaz de superar a própria condição humana e, consequentemente, ganhar a eternidade ao lado de $\mathrm{YHWH}$.

A esse respeito, o coração de Cristo tem sido, em especial, sua carne mais fetichizada nas imagens cristã referentes à sua paixão no cristianismo em geral. 0 coração é a víscera que está ligada, desde os egípcios antigos, à ideia de culpa ou de pureza, como veremos mais adiante no mito do julgamento da deusa Maat.

Assim, assemelhar-se com Cristo é buscar a vida eterna ao lado do Deus Pai. Para isso, no entanto, é preciso assumir suas qualidades. É nesse sentido que a Comunhão vem complementar as diversas outras possibilidades de mimetismo com Cristo. A Comunhão não é, para o fiel católico, uma simbologia, mas antes uma verdade. Comungar seria literalmente comer do corpo e beber do sangue de Cristo.

A semelhança entre esses dois rituais relatados acima apresenta uma problemática em torno de concepções metafísicas ligadas à temática da comunhão pela visceralidade corpórea. Fazer a comunhão com o corpo e/ou com o sangue de um outro ente significa buscar atributos que, por ventura, consideramos não os ter, ou os temos em nível precário, ou simplesmente almejamos ter ainda mais.

Mas como a mente associa a transferência de qualidades psíquicas (mentais ou anímicas) por meio de uma parte física no processo de comunhão?

Esta é uma pergunta que nos leva a uma resposta bem desconfortável, simplista e reducionista: princípios metafísicos. Esta resposta, apesar de insatisfatória, representa a ideia de que há outras questões além da física que possibilitariam a transmissão de qualidades do ente comungado para o ente que comunga.

\footnotetext{
${ }^{2} \mathrm{~A}$ prática ritual também pode ser associada ao contato tátil. Jean de Léry dá-nos um bom exemplo disso: “incrível crueldade, assim como os nossos caçadores jogam a carniça aos cães para torná-los mais ferozes, esses selvagens pegam os filhos uns após outros e lhes esfregam o corpo, os braços, e as pernas com o sangue inimigo a fim de torná-los mais valentes" (LEAN DE LÉRY, 1961, p. 157; trad. Milliet do original de 1578). O cronista entende esta prática como cruel e física, pois, para ele, não se trata de uma questão de transmissão de qualidades, mas antes de um estágio de animalização do homem, recorrendo aos instintos mais primitivos.

${ }^{3} \mathrm{~A}$ expressão "antropos", do grego antigo, significa "homem", e "phagein", também do grego antigo, significa "comer".

4Jean de Léry já havia feito análises desse tipo em 1578 na obra que foi traduzida para a Língua Portuguesa como Viagem a Terra do Brasil; cf. trad. Sérgio Milliet (1961, pp. 73-74).
} 
Poderíamos dar vários exemplos semelhantes a esses na América do Sul, antes da chegada do europeu, mas não precisamos ir adiante com os exemplos, já que buscamos analisar não antropologicamente cada um deles, mas antes alguns traços importantes para o problema da metafísica nas imagens estéticas de mitos e ritos ligados à visceralidade humana. A questão que se nos abre diante dessa estrutura ritual é: se considerarmos o ritual cristão como metafísico e o indígena como selvageria naturalista, estaremos desprezando cegamente o princípio que fundamenta os dois rituais. Por isso passaremos a verificar em que medida os dois rituais poderiam ser considerados metafísicos.

Por um lado, nutrir o corpo não é mais que um princípio natural de comer outro ente (seja ele animal, vegetal ou mineral) e de beber dos líquidos que a natureza nos disponibiliza. Esta visada natural e biológica poderia muito bem ser uma resposta para a evolução das estruturas rituais que mencionamos acima. Mas ficar com esta resposta apenas não satisfaz à maioria dos nossos leitores, tenho certeza, nem a mim próprio, confesso. Afinal, ela não explica como nós, seres humanos, associamos a dualidade entre soma e psyche em rituais como esses. Optei por utilizar essas duas expressões em grego antigo apenas para não ter que entrar na discussão se essa dualidade existe em nível de "corpo e mente" ou em nível de "corpo e alma", já que em grego antigo a expressão psyche possibilita os dois significados: "mente" e "alma" (a depender de seu contexto).

Interessa-nos o fato de que há muito, na história evolutiva da humanidade, percebemos a dualidade humana que nos é intrínseca e, provavelmente, inevitável, mesmo que apenas categorial como seria o caso entre corpo e mente. Mudando grandemente sua roupagem ou mantendo-se muito semelhante, o certo é que a dualidade humana está presente tanto na Antropofagia indígena quanto na Comunhão católica.

O ritual indígena busca a transmissão das qualidades humanas do guerreiro inimigo para o antropófago, tais como: estratégia de guerra, coragem para a batalha, força para as armas, visão apurada, resistência mental e física para a guerra, etc. Comer do corpo e beber do sangue é antes uma relação dualista entre soma e psyche, para reforçar as qualidades humanas que interligam um e outra, preparando o guerreiro para a próxima batalha e para a vida na natureza.

${ }^{5} \mathrm{~A}$ esse respeito, Frank Lestringant chama atenção para o fato de que Jean de Léry inverte o princípio dos dois rituais, em torno do cru e do cozido para defender um tipo de heresia católica ao praticar antropofagia em retorno do cru, já que do pão cozido chegar-se-ia ao cru da carne de Cristo (LESTRINGANT, 1998, p. 431).
No caso do ritual cristão, comer da carne e beber do sangue têm sido entendidos como nutrição para a alma, que precisa purificar-se e ir, assim como Cristo teria ido, para o lado de $\mathrm{YHWH}$.

Mas como a mente humana associa que qualidades psíquicas como ato de coragem, resistência mental, dentre tantas outras, podem ser transferidas a partir de um pedaço de víscera ou de um pouco de sangue, que, não podemos perder de foco, são físicos?

Uma segunda pergunta torna-se também necessária:

Que tipo de princípio dualista é esse, que, por si, beira uma concepção metafísica, mesmo que, para os indígenas, seja uma questão natural e não sobrenatural?

Não estou interessado, aqui, em demonstrar se existe ou não uma metafísica verdadeira que fundamenta tais rituais. E menos ainda naquele tipo de abordagem feita, no século XVI, por cronistas como o pastor protestante Jean de Léry, conforme vimos anteriormente, que, com a intenção de fazer seu leitor olhar de maneira mais familiarizada para as práticas do índio americano e acusar o catolicismo de retrocesso, afirma que o catolicismo pratica um tipo de canibalismo no ritual de Comunhão.

Nenhum dos dois rituais pode ser simplesmente reduzido a práticas de canibalismo, seja para educar antropologicamente ou para criar contendas entre diferentes maneiras de credo. Meu interesse, com tais exemplos, está ligado à psicossomática em torno desse processo imagético da antropofagia.

A situação contextual das duas comunhões é bastante importante para o nosso recorte temático em torno da metafísica: uma é realizada enquanto o "doador" está morto; outra enquanto o "doador" está ainda vivo. Com isso, as vísceras do doador morto seriam um tipo de promessa de melhoramento das qualidades do antropófago para a vida presente; as vísceras do doador vivo seriam, por sua vez, um tipo de promessa de melhoramento das qualidades na vida presente para se alcançar a eternidade após à morte. ${ }^{5}$

No entanto, não podemos desprezar a imagem do ato visceral da comunhão que está inserida nos dois rituais. Se Jesus ofereceu seu corpo e seu sangue para os homens, não podemos simplificar e dizer que este é o caminho para a vida metafísica, mas precisamos observar como se dá esse caminho. O caminho que Jesus abre aos homens com a última Ceia guarda a ideia também de que, assim como os índios, a Comunhão é feita a partir de um pedaço de víscera e de um pouco de sangue. Com isso, a simbologia estética nos leva para a mesma pergunta do caso indígena da comunhão: 
Como a mente associa a transferência de qualidades psíquicas (mentais ou anímicas) por meio de uma parte física no processo de comunhão em nível de crença?

O que tentaremos fazer é verificar se princípios psicossomáticos podem conduzir para algumas especulações acerca de tais problemáticas. Para nos auxiliar nessas problemáticas, apresentaremos outras duas imagens míticas ligadas às vísceras e ao sangue humanos na próxima seção.

\section{Mito de ressurreição}

O mito de Osíris é provavelmente a referência mais antiga de ressurreição de nossa história registrada. Osíris é o deus egípcio que, traído e esquartejado pelo irmão Seth, teria sido remembrado e ressuscitado pelas irmãs Ísis e Néftis. ${ }^{6}$

Osíris se tornara, no antigo Egito, símbolo de preservação do cadáver, contra o desmembramento dado pela consequência da morte. A ideia, por trás do mito, está no fato de que a preservação do cadáver, contra o desmembramento ósseo, tornaria possível uma ressurreição íntegra no reino dos deuses. Precisaremos entender, nesse sentido, o significado de "integridade de ressurreição".

Muitas orações e rituais dedicados ao deus Osíris, no Livro para sair à $\mathrm{Luz}^{7}$, que foi traduzido tendenciosa e livremente por Livro dos Mortos, relata tal preocupação em forma de encantamento a ser proferido quando da jornada do morto no mundo dos mortos. Vejamos um exemplo sintomático dessa questão no capítulo 154, intitulado "Para que o corpo não pereça" do Livro para sair à Luz:

Oh Osíris, meu Pai divino, (...) Possa eu, depois da morte, ignorar a putrefação, este destino comum a todos os animais e a todas as feras que se arrastam criadas por diferentes deusas! Pois quando, depois da morte, a Alma empreende seu voo, o cadáver se liquefaz, seus ossos se desarticulam e se dissolvem e a carne impregnada de mau cheiro apodrece, os membros caem aos pedaços e tudo se transforma em um líquido nauseabundo (Livro dos mortos, cap. CLIV) ${ }^{8}$

O mito de Osíris fundamenta o ritual de ressurreição egípcio, que se dá tanto pelo ente metafísico que chamamos atualmente de "alma", quanto pelo corpo. Começa por aí a ideia de "integridade de ressurreição". Digo que "começa" porque além desses dois princípios, os egípcios consideram outros seis princípios que precisam estar íntegros, para a ressurreição acontecer. Mas o que mais chama atenção é o fato de que o corpo físico, depois de sua morte física, precisa ser preservado contra o desmembramento ósseo, contra o apodrecimento e a dissolução da carne, contra a liquefação.
Osíris seria símbolo da ressurreição íntegra, representada em nossas pobres palavras pela alma e pelo corpo. Ele próprio teria passado pela morte, pelo desmembramento e pela ressurreição, por isso ele fundamentaria todo esse processo, operando em favor do morto ou contra ele.

Para entendermos o mito de ressurreição em sua integridade, temos de ter uma breve noção da complexidade egípcia em relação aos nove princípios que constituem a existência humana: 1) (Khat) é o corpo físico; 2) (Ka) é um duplo do corpo físico, uma reserva de força vital; 3) (Ba) um tipo de ligação anímica do corpo físico; 4) (Akhu) é a parte imortal, a união entre $\mathrm{Ka}$ e $\mathrm{Ba}$, que guarda o intelecto, os desejos e as intenções; 5) (Khaibit) é a sombra; 6) (Sahu) é o corpo espiritual, que guarda as habilidades mentais; 7) (Sekhem) é a personificação incorpórea; 8) (Ib) é o coração celeste, onde ficam os registros das ações boas e más; 9) (Ren) é o nome verdadeiro. ${ }^{9}$

É nesse sentido que todo preparo do embalsamamento do corpo físico, Khat, é necessário na visão do antigo egípcio. Só assim seu duplo corpóreo, Ka, juntamente com sua ligação anímica, $\mathrm{Ba}$, podem, enquanto imaterialidade intelectiva, desiderativa e intencional, Akhu, passar para a existência eterna. A preservação do corpo físico, por sua vez, representa também a preservação de atributos e habilidades do morto, além, é claro, em nível simbólico, da preservação dos registros de suas ações. A junção entre o duplo corpóreo e sua ligação anímica não está no nível da dualidade corpo e alma conhecida em nossa era. ${ }^{10}$ Todos os princípios humanos precisam ser unidos e preservados, inclusive o corpo físico, para que a vida eterna seja alcançada em toda sua integridade.

Nesse mesmo contexto da jornada do morto, há uma importante imagem para nossa temática: seu julgamento pelos deuses. Nesse julgamento, o coração, Ib, é pesado e, a partir do resultado da balança, a sentença em favor do morto ou contra ele é tomada. $\mathrm{O}$ tribunal do julgamento é constituído por quarenta e dois deuses, cuja presidência é feita por Osíris, o deus da ressurreição. O julgamento consiste basicamente numa balança em que se coloca, de um lado, o coração do morto, e, do outro, uma pena ${ }^{11}$ ou uma estátua ${ }^{12}$ (a

${ }^{6} \mathrm{Cf}$. a versão traduzida por Bresciani (2001, p. 462).

${ }^{7}$ Cf. Bresciani (2001, p. 417).

${ }^{8}$ Trad. de Negraes (2005).

${ }^{9} \mathrm{Cf}$. Poortman (1978).

${ }^{10} \mathrm{Cf}$. Dunand; Lichtenberg (2002, p. 41).

${ }^{11} \mathrm{~A}$ pena era de avestruz, pois representava a verdade (CHRISTOPHE, 1971, p. 81).

${ }^{12} \mathrm{~A}$ estátua era a da deusa da justiça Maât (GIORDANI, 1972, p. 114). 
depender da versão). Observemos o capítulo 30, intitulado "Para que o coração do morto não seja rejeitado", e, além deste trecho, uma brevíssima parte do capítulo 125, intitulado "Palavras para pronunciar na entrada do santuário de Maat", a deusa egípcia do julgamento, do Livro para sair à Luz:

\begin{abstract}
Meu coração 'Ib' me vem de minha Mãe celeste. Meu coração 'hati' me vem da minha vida na Terra. Que não sejam levantados falsos testemunhos contra mim! Que os juízes divinos não me repudiem! Que sejam verdadeiros os testemunhos concernentes a minhas ações na Terra ante o vigilante da BALANÇA e o divino senhor do Amenti' ${ }^{13}$. Salve, oh! meu coração 'Ib'!. (Livros dos Mortos, cap. XXX)

Tua balança, em verdade, está em nosso coração, onde há de buscá-la

(Livros dos Mortos, cap. CXXV)
\end{abstract}

Pesar o coração significa verificar tais registros da vida física na terra. No coração, portanto, ficariam registrados o resultado somático das intenções das ações do morto. Pesá-lo significa verificar os registros viscerais do homem como um todo. Em nível psicológico, o registro é fornecido pelo próprio morto. Não são os deuses que o acusam. O coração seria o registro mais fiel das sensações e dos sentimentos do morto: culpado ou inocente.

Se for considerado puro, o morto ressuscita e vai para o lado dos deuses, assim como teria ido Osíris.

Se levarmos a simbologia do embalsamamento às últimas consequências, teremos de aceitar que a ressurreição só pode ser completa se o corpo físico for preservado da putrefação e da liquefação proveniente da morte, para que possa ressuscitar num tipo de corpo imaterial, juntamente com sua ligação anímica, que se entende por alma. Se observarmos ainda mais de perto a imagem, somos obrigados e aceitar que a ressurreição não se dá com a parte visceral do corpo físico. Isto indica, em forte medida, que essa nova existência, pela unidade de um tipo de físico duplo (imaterial) e de um metafísico, dá-se sem a visceralidade física, que simboliza, fortemente, as sensações e os sentimentos humanos. A vida imutável, eterna, pura, metafísica, dáse, portanto, sem as intempéries da existência física, simbolizadas nas vísceras e no sangue humanos.

\footnotetext{
${ }^{13}$ Amenti era o nome que os egípcios davam ao templo onde as ligações anímicas do corpo eram reunidas depois da morte, para serem julgadas por Osíris.

${ }^{14} \mathrm{Em}$ sentido simbólico, o sangue e a água representam a parte humana e parte divina de Cristo; cf.: "sem

derramamento de sangue não há remissão [de pecados]" $(\mathrm{Hb}$

9:22), e a água representa a purificação moral (Jo 5:3; Ef 5:26).

${ }^{15}$ Bíblia Sagrada (1989).
}

Um dos mitos mais conhecidos de ressurreição da nossa história ocidental é o de Cristo, presente no Novo Testamento. De acordo com os quatro evangelistas, Jesus teria sido uma divindade que veio à vida terrestre como ser humano. Sua morte revela um profundo caráter de expiação humana, e sua ressurreição uma profunda simbologia de ascensão divina.

Sua expiação representa mais do que dor, sofrimento e humilhação: a exposição de sua carne flagelada e do sangue derramado representa a aceleração do estado de putrefação do corpo, à primeira vista, e simboliza a aceleração de sua expiação e purificação, numa visada mais profunda. O espetáculo sanguinário de Cristo simboliza um tipo de limpeza das impurezas humanas: lato senso, se entendermos sua paixão como salvação para toda humanidade; stricto senso, se entendermos sua paixão como salvação individual.

Segundo a versão canonizada do mito, Jesus não foi embalsamado, mas, no Evangelho de João (19: 31-37), é possível perceber fortes semelhanças simbólicas com a ideia de etapas necessárias para um embalsamamento. Vamos observar à passagem:

Os judeus temeram que os corpos ficassem na cruz durante o sábado, porque já era a preparação e esse sábado era particularmente solene. Rogaram a Pilatos que se Ihes quebrassem as pernas e fossem retirados. Vieram os soldados e quebram as pernas do primeiro e do outro, que com ele foram crucificados. Chegando, porém, a Jesus, como o vissem já morto, não lhe quebraram as pernas, mas um dos soldados abriu-lhe o lado com uma lança, e imediatamente saiu sangue e água. ${ }^{14} \mathrm{O}$ que foi testemunha deste fato $\mathrm{o}$ atesta (e o seu testemunho é digno de fé, e ele sabe que diz a verdade) a fim de que vós creiais. Assim se cumpriu a Escritura: Nenhum dos seus ossos será quebrado (Ex 12, 46): E diz em outra parte a Escritura: olharão para aquele que transpassaram (Jo. 19: 31-37). ${ }^{15}$

Os dois ladrões, crucificados juntamente com Cristo, tiveram suas pernas quebradas, para que se sufocassem e morressem antes do sábado santo. Jesus, por estar morto, teve um dos lados perfurado pela lança de um soldado romano. O fato é que a figura do Jesus canônico traz consigo dois importantes elementos estéticos que remontam à ideia da preservação do corpo contra a putrefação e o desmembramento ósseo: em primeiro lugar, pela lança empunhada por um soldado romano, que Ihe trespassa a lateral do corpo e lhe esvai líquidos fluídicos corpóreos; em segundo lugar, pela ideia de que nenhum osso lhe foi quebrado.

Jesus do ponto de vista biológico, grosso modo, apresenta em sua imagem mítica uma retirada de grande quantidade de seus líquidos fluídicos e um corte lateral, 
por onde no embalsamamento egípcio tiravam-se as vísceras, além é claro da preservação óssea contra o desmembramento do cadáver. Nesse sentido, a figura de Jesus representa um nível íntegro e elevado de ressurreição.

Sua expiação, na mesma medida da crença antiga dos egípcios, dá-se, em nível biológico, pela retirada dos líquidos fluídicos e pela simbologia do corte lateral (que aludimos aqui às vísceras). Basta olharmos para sua aparição a Tomé, com as chagas abertas, que são penetradas pelo dedo de Tomé, mas sem a presença de qualquer líquido fluídico ou exposição visceral. Diferentemente de sua imagem na cruz, seu corpo ressuscitado, ao que se pode notar, está sem as marcas das emoções e dos sentimentos naturais e viscerais de um ser humano, já imortalizado.

A questão que nos interessa nos dois mitos não é o fato de verificarmos a veracidade ou a falsidade dos acontecimentos; um bom Estudo Mitológico não se presta a este serviço. O que de fato nos interessa é analisar possibilidades psicológicas que possam ter fundamentado imageticamente princípios metafísicos ao longo de nossa história humana. Para isso, faremos, na seção a seguir, algumas considerações psicossomáticas em torno dos problemas levantados até aqui.

\section{Psicossomática e ideias metafísicas}

Do ponto de vista biológico, órgãos como baço, fígado, coração, além de líquido fluídicos como o sangue, são grandes responsáveis pela proliferação de microrganismos, que geralmente partem, após à morte, do intestino e da pele. ${ }^{16} \mathrm{O}$ artigo liderado por $\mathrm{Can}^{17}$ (Pesquisador do Programa de Ciência Forense da Universidade do Estado do Alabama), intitulado "Distinctive thanatomicrobiome signatures found in the blood and internal organs of humans" inaugura - Tanatomicrobioma, que em minhas palavras é um tipo de análise que indica biomarcas (marcadores da desintegração e da putrefação) da transformação de um cadáver. Nesse exame, analisam-se pequenas partes do baço, do fígado, do coração, do cérebro e do sangue, para identificar micro-organismos responsáveis pela decomposição de um cadáver. ${ }^{18}$ Quanto ao sangue, sabemos que é um grande responsável pelo processo de degradação das células no processo de autólise (ou autodigestão) de um cadáver, em função da hipoxia, o fim da oxigenação dos tecidos:
Nós sabemos que as células humanas tornam-se hipóxicas, porque a circulação de sangue cessa quando o coração para de bombear (GEVERS, 1975). A hipoxia desencadeia a libertação de fatores intracelulares que causam a degradação organizada de organelas celulares por meio das enzimas autolíticas (PROSKURYAKOV et al., 2003). (CAN e al. 2014, p. 1)19

Contra o processo de decomposição, putrefação e liquefação cadavérica, a antiga civilização egípcia praticava o embalsamamento - técnica que consistia na retirada dos órgãos viscerais, por um corte lateral, e dos líquidos fluídicos, por ressecamento, para a mumificação de um cadáver. A ressurreição canônica de Cristo também apresenta algumas dessas imagens.

As vísceras e os líquidos fluídicos como o sangue, por exemplo, indicam algum tipo de registro humano do pútrido, do demasiado humano, tendo em conta as consequências biológicas ${ }^{20}$ percebidas pela mente humana. Assim, a imagem mítica da ressurreição recorre à ideia de que o corpo deve ser preservado para a eternidade sem a visceralidade pútrida da morte.

A comunhão com partes viscerais de outro ente é também uma imagem que indica a ideia de registro humano, mas, por outro lado, indica um registro positivo, ou seja, as qualidades do ente sacrificado, entendido como qualificado, são transmitidas para aquele que comunga de sua carne e de seu sangue.

Assim, quando as vísceras e o sangue são registros negativos, eles precisam ser retirados. Mas quando eles são registros positivos, precisam ser comungados.

Para dar continuidade em minhas considerações contarei uma breve historinha.

\footnotetext{
${ }^{16}$ Depois da morte, o sistema imunológico para e os microorganismos como bactérias e fungos proliferam-se pelo corpo, partindo do intestino e da pele $(2012$, p. 312)

${ }^{17}$ Can, Ismail; Javan, Gulnaz T.; Pozhitkov, Alexander E.; Noble, Peter A (2014).

${ }^{18}$ Indicamos também a leitura do recente artigo liderado por Javan (et al.): “Human Thanatomicrobiome Succession and Time Since Death" (2016).

${ }^{19} \mathrm{Cf}$. original: "We do know that human cells become hypoxic because blood circulation ceases when the heart stops pumping (GEVERS, 1975). Hypoxia triggers the release of intracellular factors that cause the organized degradation of cellular organelles by autolytic enzymes (PROSKURYAKOV et al., 2003)".

${ }^{20} \mathrm{~A}$ tese biológica acerca das técnicas primitivas de mumificação mais aceita tem sido relacionada ao ambiente natural do Egito, que naturalmente teria certa capacidade de dessecar os cadáveres. Taylor chega a afirmar que a mumificação natural teria levado o antigo egípcio a associar que há outros princípios humanos que perduram depois da morte física, mas que depende, nesse sentido, da preservação do corpo físico (TAYLOR, 2001, p. 46).
} 
Observando um gato vadio que apareceu na casa da minha mãe e ofereceu-se a um tipo de adoção, percebi que ele também tem seus algozes. Todo dia há um ou dois pombos que se aproveitam de sua distração, enquanto brincamos com ele, para roubar-lhe um pouco de comida. Dia desses, ele até chegou a matar um desses pombos, mas deixou o cadáver, lá, intacto. No início dessa suposta adoção, vi-o caçando qualquer coisa no jardim para comer, quando ainda não estava propriamente acostumado com a ração.

Os outros animais também têm seus inimigos, como o pombo para o gato da minha mãe - e também seus amigos, como minha mãe e eu nos tornamos para ele. Esse não é, definitivamente, um privilégio humano. Mas é possível que nossa mente tenha uma aptidão especial para formulações de princípios metafísicos. Não estou afirmando que outros animais não tenham nenhum tipo de formulação mental acerca de princípios metafísicos, mas este não é nosso recorte temático neste trabalho. O que estou sugerindo, em outras palavras, é que, mais que mero formuladores, temos uma aptidão natural e frequente para associações metafísicas. Também não estou afirmando, com isso, se existem ou não instâncias metafísicas; isto deixo por conta de cada leitor.

Depois desta historinha, gostaria de finalizar este trabalho, portanto, com a tentativa de responder a uma pergunta: como a mente associa a transferência de qualidades psíquicas (mentais ou anímicas) por meio de uma parte física do corpo?

O intuito desta pergunta é tentar dimensionar como associamos as vísceras e o sangue como algo que, em primeiro lugar, guarda registros qualitativos somáticos e psíquicos, e, em segundo lugar, como associamos a transmissão do nível somático para o nível psíquico consideremos psyche como "alma" ou como "mente", não importa.

Para tratar deste assunto, temos de entrar na teoria psicossomática. A teoria consiste na ideia de que as instâncias mentais, ou anímicas se preferirmos entender que temos uma "alma", podem ser somatizadas (materializadas) ao nosso corpo.

${ }^{21}$ Demonstrei recentemente, na Tese Doutoral intitulada Katabasis e psyche em Platão, defendida na Universidade de Coimbra em julho 2015, que a teoria que pensávamos ser fundamentada pela psicanalise já havia sido apresentada e fundamentada por Platão mais de dois mil anos antes das discussões psicanalíticas. Isto, por questões de direcionamento temático não vamos apresentar aqui, neste trabalho, mas recomendo a leitura da Tese.

${ }^{22}$ Recomendamos os artigos de Komaki et al. "Prospects of Psychosomatic Medicine" (2009) e o de Nakao e Barsky "Clinical application of somatosensory amplification in psychosomatic medicine" (2007).
Minha sugestão, neste momento, é que a teoria psicossomática é antes uma percepção intuitiva da mente humana, que se reflete em diversas imagens míticas e rituais mesmo antes de suas conjecturas teóricas no mundo clássico e no mundo moderno. ${ }^{21}$ Sugiro também que suas consequências práticas são uma realidade, independentemente de termos respostas para as questões metafísicas. Isto pretende levantar a hipótese de que os nossos ancestrais já haviam percebido a relação dualista que existe entre o corpo e uma outra coisa qualquer que é capaz de pensar o próprio corpo, seja essa coisa uma "mente" ou uma "alma".

Não é exclusividade clássica nem moderna o conhecimento de que as vísceras e o sangue são vitais para a vida animal e estão diretamente ligados a princípios psicossomáticos. Não estou dizendo, com isso, que a medicina atual não esteja fazendo avanços em torno desse tópico. O grupo do Doutor Nakao (da Escola de Medicina da Universidade de Teikyo, em Tokyo - Japão), e do Doutor Barsky (do Departamento de Psiquiatria da Escola de Medicina de Harvard, em Boston, no EUA) é apenas um dos muitos exemplos de tentativa de mensuração observável de aspectos psicossomáticos. ${ }^{22}$

O que estou dizendo é que tais observações já eram feitas desde muitos milênios pela humanidade. A medicina egípcia já havia formulado conhecimentos muito vastos sobre essa questão: a prática de mumificação, por si, é uma prova disso. Associamos, desde cedo (talvez na fase ainda pré-consciente) as vísceras como vitalidade. O coração, apenas para dar um exemplo, conforme vimos para os antigos egípcios, guardaria o registro das emoções e dos sentimentos em geral, e, por ele, os deuses poderiam, segundo conta o mito da balança, verificar se o morto teve ou não uma vida justa.

O fato é que os primeiros ensaios acerca da psicossomática já estavam feitos inconscientemente em várias imagens míticas e rituais antigas antes mesmo dos pensadores clássicos e modernos.

Intuitivamente, a humanidade sentiu e sente que suas felicidades e infelicidades ficam, de alguma maneira, registradas em nossa visceralidade. É bem provável que, assim como tenhamos associado que os males da infelicidade prejudicam nossa vitalidade visceral (e estou me referindo não apenas a emoções e sentimentos, mas à somatização factual de determinadas enfermidades), o ser humano tenha percebido que os bens da felicidade também causam somaticamente boa saúde à nossa vitalidade visceral. 
Se a mente humana percebeu que a retirada das vísceras e dos líquidos fluídicos de um cadáver provocaIhe a preservação contra a putrefação da morte eterna, a mente humana também percebeu que vísceras e sangue saudáveis podem ser sinal de boa qualidade de vida. Nesse sentido, o contato com vísceras e sangue não saudáveis causaria putrefação; por outro lado, o contato com vísceras e sangue saudáveis causaria purificação. Associá-los a concepções metafísicas seria uma questão razoável para muitas culturas. A psyche humana, pensando seu próprio soma, percebe, mesmo que intuitivamente, o processo maléfico ou benéfico em torno da relação daquilo que pensa seu corpo, seu próprio corpo e outros corpos. Não estou afirmando que o homem primitivo tivesse associações conscientes desse processo, mas certamente esse é um conhecimento natural da mente humana desde o início do estado evolutivo que consideramos e chamamos "mente humana".

Esse processo, no entanto, não pode ser considerado apenas associativo, visto que traz consequências práticas e reais transmitidas de um soma para uma psyche. Não precisamos aceitar a existência de uma relação metafísica real para percebermos que tais princípios trazem benefícios reais à vida psíquica de um indivíduo ou mesmo a muitas psychai ligadas a uma crença em uma determinada cultura.

Assim, analisando a dualidade perceptiva própria do ser humano, percebemos que a ideia de nutrição funciona, na verdade, como fundamento para a ideia de transmissão das qualidades físicas ou mentais/ anímicas por meio de um pedaço de víscera ou um pouco de sangue. É nesse sentido que percebemos que a psicossomática não apenas já havia sido descoberta pelos antigos, como também revela que isso é princípio intrínseco à vida humana.

\section{Considerações finais}

Pelo fato de estarmos em um Congresso de Estética, Hermêutica e Semiótica, introduzido no Programa de Pós-Graduação de Arquitetura e Urbanismo da Universidade de Brasília - UnB, não poderia deixar de me cobrar uma breve ligação entre a visceralidade humana com temáticas da casa, onde estamos sendo recebidos nesta tarde.

Os templos sacros da antiguidade, cujos modelos influenciam ainda as construções de templos sacros dos dias atuais, espelham esse tipo de conhecimento.

Se analisarmos, muito brevemente, dois modelos básicos de sacralidade arquitetônica, a pirâmide egípcia e o templo cristão, notaremos que:
1- as pirâmides tinham a função de preservar, em suas bases profundas, o corpo físico (protegendo-o da putrefação e do desmembramento), para que sua ligação anímica e seu corpo imaterial fossem projetados para um caminho existencial puro e eterno. Para isso, no entanto, o corpo físico deveria ser embalsamado, para que o corpo imaterial (sem a visceralidade humana) pudesse, em confluência com sua ligação anímica, ir para uma existência superior ao lado de Ra. Este caminho existencial puro e eterno, grosso modo, está representado pela própria morfologia e sintaxe do edifício piramidal. Aconselhamos a leitura do artigo “Pirâmide egípcia: espaço sacro de reorganização cósmica", que publiquei, em 2012, na Revista Estética e Semiótica deste mesmo Programa de PósGraduação de Arquitetura e Urbanismo da UnB, pois não podemos nos render a este tema aqui neste trabalho;

2- quanto aos templos cristãos, delimitaremos o exemplo aos templos clássicos adaptados para os cultos cristãos. Sua função básica, mantida até os nossos dias, era a interiorização do ritual, em sentido vivencial. Mas, em sentido metafísico, serviu para criar uma dualidade entre o mundo físico, externo, e um mundo que se reclama metafísico, interno ao templo. Assim, os templos cristãos adaptados dos templos clássicos representam a separação daquilo que intensificará as características profanas de um fiel com aquilo que o direcionará para a vida eterna e pura. Com isso, o fechamento do peristilo dos templos clássicos dedicados à deusa Atena para a adaptação dos templos cristãos dedicados à Maria representam, nesse tema da visceralidade humana, a superação das sensações e sentimentos registrados nas vísceras e no sangue do fiel. Em outras palavras, o templo cristão sugere que, sendo humano, o fiel se espelhe na vida de Cristo (que superou sua visceralidade humana e ressuscitou em uma vida existencial pura e eterna) e siga uma vida que se baseie na expiação e purificação de sua própria visceralidade. A respeito da adaptação do templo clássico para templo cristão, sugiro a leitura do artigo "O fechamento do peristilo do templo clássico de Atena e sua reutilização como templo cristão dedicado a Maria", que publiquei, em 2015, na Revista Estética e Semiótica deste Programa de Pós-Graduação, e também o artigo "Templo clássico de Atena / templo cristão de Maria: realidades psíquicas reveladas" que publiquei na Revista Paranoá, também deste mesmo Programa de PósGraduação da Universidade de Brasília - UnB. 
Deixo, para finalizar, meus agradecimentos ao Programa e aos Organizadores e colaboradores do Núcleo de Estética, Hermenêutica e Semiótica (NEHS), presidido pelo Professor Doutor Flávio René Kothe. E deixo também meus incentivos para estudantes e pesquisadores que trabalhem mais com temas transversais e multidisciplinares, pois nossos dias estão de fato clamando por isso.

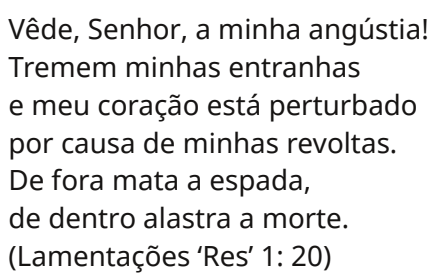

\section{Referências bibliográficas}

ANÔNIMO. O livro dos mortos do antigo Egito. Trad. Edith de Carvalho Negraes. São Paulo: Hemus, 1982. 356p.

ANÔNIMO. Bíblia Sagrada. Edição Claretiana, 1989.

CAN, Ismail; JAVAN, Gulnaz T.; POZHITKOV, Alexander E.; NOBLE, Peter A. “Distinctive thanatomicrobiome signatures found in the blood and internal organs of humans" in Journal of Microbiological Methods, vol. 106, 2014, pp. 1-7.

COUTINHO, Luciano. Katabasis e psyche em Platão. Tese $304 f$ (Doutorado em Estudos Clássicos / Filosofia Antiga). Instituto de Estudos Clássicos, Universidade de Coimbra, Coimbra, 2015a.

“O fechamento do peristilo do templo clássico de Atena e sua reutilização como templo cristão dedicado a Maria", in Revista Estética e Semiótica (RES), vol. 5, n², 2015b, pp. 71-82.

. "Templo clássico de Atena / templo cristão de Maria: realidades psíquicas reveladas", in Revista Paranoá, n 16, 2016, pp. 121-128.

JAVAN, Gulnaz T.; FINLEY, Sheree J.; CAN, Ismail; WILKINSON, Jeremy E.; HANSON, J. Delton; TARONE, Aaron M. "Human Thanatomicrobiome Succession and Time Since Death" in Scientific Reports, 2016, pp. 1-9.

CHRISTOPHE, Micheline. "O Antigo Egito" in Enciclopédia Bloch, n 51, 1971, pp. 75-81./ n 52, 1971, pp. 75-81./ n 53, 1971, pp. 108-114./ n 54, 1971, p. 93-98./ n 55, 1971, pp. 119-124.

DUNAND, F.; LICHTENBERG, R.. Les Momies et la Mort en Égypte. Paris: Errance, 2002 [1 ${ }^{\mathrm{a}}$ ed. 1998].
GÂNDAVO, Pero de Magalhães. Tratado da Terra do Brasil. História da Província Santa Cruz. Belo Horizonte: Itatiaia, 1980. [Original publicado em 1576].

GEVERS. W. "Biochemical aspects of cell death" in Forensic Science, vol. 6, n 1-2, pp. 25-9.

GIORDANI, Mário Curtis. História da antiguidade oriental. Petrópolis: Vozes, 1972.

GUNN, Alan; PITT, Sarah. "Microbes as forensic indicators", in Tropical biomedicine, vol. 29, n³, 2012, pp. 311-330.

KOMAKI, Gen; MORIGUCHI, Yoshiya; ANDO, Tetsuya; YOSHIUCHI, Kazuhiro; NAKAO, Mutsuhiro. "Prospects of Psychosomatic Medicine" in Biopsychosocial Medicine, 2009, pp. 1-7.

LÉRY, Jean de. Viagem à Terra do Brasil (colóquio na língua brasílica e notas tupinológicas de Plínio Ayrosa). Belo Horizonte: Editora Itatiaia / São Paulo: Edusp, 1980. [original publicado em 1578].

LESTRINGAT, Frank. O Canibal: grandeza e decadência. Brasília: Editora da UNB, 1997.

. "A Outra Conquista: os huguenotes no Brasil" in A descoberta do Homem e do Mundo. São Paulo: Minc/ Funarte / Companhia das Letras, 1998. pp. 419-439.

Lichtenberg, R., (2000). "Aspects Techniques de la Momification". Dossiers d'Archéologie, n² 252, pp. 30-37.

NAKAO, MUTSUHIRO; BARSKY, Arthur J.. “Clinical application of somatosensory amplification in psychosomatic medicine" in Biopsychosocial Medicine, 2007, pp. 1-7.

PACSKOWSKI, Sebastian; SCHÜTZ, Stefan (2011). "Postmortem volatiles of vertebrate tissue" in Applied Microbiology and Biotechnology, vol. 91, 2011, pp. 917-935.

POORTMAN, Johannes Jacobus. Vehicles of consciousness: The concept of hylic pluralism. Illinois: Theosophical Pub. House, 1978.

STADEN, Hans. Descripção verdadeira de um paiz de Selvagens, Nus Ferozes e Cannibaes, Situado no Novo Mundo América, Desconhecido na Terra de Hessen antes e depois do nascimento de Christo, até que, ha dois anos, Hans Staden de Homberg, em Hessen, por sua própria experiencia e agora a dá a luz pela segunda vez, diligentemente, augmentada e melhorada. Ed. Theodoro Sampaio, Rio de Janeiro, 1930. [original publicado em Marpurgo,1557].

TAYLOR, J. H.. Death and the Afterlife in Ancient Egypt. Londres: The British Museum Press, 2001. 
